Journal of American Studies, 56 (2022), 4, 538-564

(C) The Author(s), 202 r. Published by Cambridge University Press in association with the British Association for American Studies. This is an Open Access article, distributed under the terms of the Creative Commons Attribution licence (https://creativecommons.org/licenses/by/4.o/), which permits unrestricted re-use, distribution, and reproduction in any medium, provided the original work is properly cited.

doi:10.1017/S0021875821001250 First published online 29 November 2021

\title{
"A Sort of Public Living Room": Ignorance and the Racial Management of Disorder in Postwar Los Angeles
}

\author{
VINCENT CHABANY-DOUARRE
}

Exploring sanitation in postwar Los Angeles, this article argues that as white voluntary groups formed task forces to clean up the city, they endangered Mexican and black Angelinos by endorsing solutions to urban welfare defined by antistatism and carceralism. I read these activities through the lens of white ignorance, whereby white Americans elaborated folk knowledge of successful urbanism on their own terrain and terms, which had no capacity to attend to other classes and races. I treat white ignorance not as a cognitive defect or proxy for innocence, but rather as a structural condition of postwar urban political economy.

\section{INTRODUCTION}

"Open garbage cans, fly-blown and stinking, stand before restaurants at 9 a.m., awaiting their absent owners' pleasure. Temporarily deserted store fronts gape like infected eyes, with the sweepings and leavings of days festering on their adjacent sidewalks." This was Los Angeles in the summer of 1946 , as seen through the eyes of Los Angeles Times columnist James Bassett. In a threepart series, Bassett described a city overflowing with grime, vermin, and trash. A subsequent letter-writing campaign to the Times showed that many Angelinos agreed with Bassett: Los Angeles was filthier than ever, and they had had enough. ${ }^{\text {I }}$ This article explores a popular response to this crisis:

Strand Campus, King's College London. Email: vincent.chabany-douarre@kcl.ac.uk.

I "Los Angeles One of Dirtiest Cities: Survey of Area within Mile Radius of Civic Center Gives Sorry Picture," Los Angeles Times, 30 July 1946, I; "City Debris Laid to Carelessness: Laws Exist against Desecration, but Wartime Letdown Still Rules," Los Angeles Times, 3 I July 1946, I; "Ways to Clean Up Los Angeles Told: Mayor and City Bureaus Admit Job of Ending Debris Growing Tougher," Los Angeles Times, I Aug. I 946 , I. 
cleaning drives, or cleanups. During cleanups, local residents picked up litter, painted trash cans, and planted trees in a particular suburb, neighbourhood, or street. Bassett's exposé prompted a Labor Day cleanup involving I 22 civic organizations, including forty-two chambers of commerce and twenty-two women's clubs. ${ }^{2}$ As I will argue, cleanups were a pointed and racialized intervention in urban political economy: as cleanup leaders worked to better the sanitation of Los Angeles, they advocated for an urban order which positioned white property owners as the city's rightful proprietors, tolerating state action only insofar as it advanced their own priorities, and ignoring the needs and realities of other races and classes.

Cleanups were led by private citizens affiliated through chambers of commerce and service clubs such as the Rotary, Lion, and Kiwanis. Such groups federated entrepreneurs and well-to-do homeowners, who funded cleanups from their dues as well as donations from corporations and local businesses. During the postwar period, cleaning drives contended with Los Angeles's explosive growth, which sharply tested the city's ability to provide healthful urban space. This disorder mapped onto racial disparities, as the neighbourhoods that provoked the most alarm were those with significant black and Mexican populations, marked by segregation-induced overcrowding and municipal disinvestment. A wealth of scholarship, spanning centuries and continents, has established how panics over order and hygiene are inextricably bound up with histories of oppression. ${ }^{3}$ Kathleen Brown has argued that European colonization unleashed intense impulses to delineate a rational, modern, and-crucially-clean Western body, as contrasted with that of the conquered black subject. ${ }^{4}$ Historians of nineteenth-century America, meanwhile, have found that middle-class urban reformers could be driven by genuine sympathy for immigrants and the poor, but that they also recurrently

2 “Times' Cleanup Drive Supported: C. of C. Pledges Help to Bring Los Angeles Back as 'White' Spot," Los Angeles Times, 2 Aug. 1946, I; "All-Out Campaign for Cleanup of Los Angeles to Begin Next Month: Chamber Sends Announcements to I22 Civic Groups," Los Angeles Times, I 2 Aug. 1946, I.

${ }^{3}$ Classic accounts include Mary Douglas, Purity and Danger: An Analysis of Concepts of Pollution and Taboo (London: Routledge, 1966); Michel Foucault, Security, Territory, Population: Lectures at the Collège de France: 1977-78 (Basingstoke: Palgrave Macmillan, 2009). For examples of more recent historical and theoretical studies see Natalia Molina, Fit to Be Citizens? Public Health and Race in Los Angeles, 1879-1939 (Berkeley: University of California Press, 2006); Neel Ahuja, Bioinsecurities: Disease Interventions, Empire, and the Government of Species (Durham, NC: Duke University Press, 2016); Linda Lorraine Nash, Inescapable Ecologies: A History of Environment, Disease, and Knowledge (Berkeley: University of California Press, 2006).

${ }^{4}$ Kathleen Brown, Foul Bodies: Cleanliness in Early America (New Haven, CT: Yale University Press, 2009), 5-13. 
imposed the authority of middle-class norms. ${ }^{5}$ As classes and races met, notions of hygiene served to reify and legitimate hierarchies, and to endow a racialized whiteness with augmented social worth. While such coercive dynamics reverberated in twentieth-century American cleanups, I propose that the mid-century era offered another avenue for white racialization, one brokered less in the form of overt contempt for the other, but rather through white ignorance, drawing from philosopher Charles Mills. I argue that cleanup leaders endorsed social models that exclusively served their contexts and interests as white property owners: although their activities generally avoided mention of race, they were so deeply ethnocentric that while acting both as social events and as springboards for public policy, cleanups decentred the needs of other races and classes.

Indeed, America's understanding of race in the postwar period underwent a seismic change, characterized by sociologist Howard Winant as the "racial break." According to Winant and others, by 1945, wartime rhetoric of racial equality, global anticolonial movements, and pressure from the Soviet Union, which used America's appalling race relations to challenge its postwar ascendancy, all contributed to driving overt racism underground, even as white supremacy remained a dominant ordering force of American society. ${ }^{6}$ As such, navigating race in postwar America means comprehending a base of material dispossession and an ideological superstructure which could and did take the form of contempt and antiblackness, but also that of denial, feigned innocence, and what Mills terms white ignorance. Mills argues that as racism became increasingly understood as a psychological ill

s Gwendolyn Wright, Building the Dream: A Social History of Housing in America (New York: Pantheon Books, 1981), I29-50; Cindy Sondik Aron, Working at Play: A History of Vacations in the United States (New York: Oxford University Press, 1999), I 88-93; Suellen M. Hoy, Chasing Dirt: The American Pursuit of Cleanliness (New York: Oxford University Press, 1995), I I4-21. Some of the more sympathetic portraits of public health reforms nonetheless acknowledge their ambivalent relation to paternalism and eugenics. See John Louis Recchiuti, Civic Engagement: Social Science and ProgressiveEra Reform in New York City (Philadelphia: University of Pennsylvania Press, 2007), 9397; Jennifer Lisa Koslow, Cultivating Health: Los Angeles Women and Public Health Reform (New Brunswick, NJ: Rutgers University Press, 2009).

${ }^{6}$ Howard Winant, The World Is a Ghetto: Race and Democracy since World War II (New York: Basic Books, 200I). Winant's theory built on and has been reiterated by the work of a number of scholars. See especially Peggy Pascoe, "Miscegenation Law, Court Cases, and Ideologies of 'Race' in Twentieth-Century America," in Vicki Ruíz and Ellen Carol DuBois (eds.), Unequal Sisters: A Multicultural Reader in U.S. Women's History (New York: Routledge, 2000), 163-77; Penny M. Von Eschen, Race against Empire: Black Americans and Anticolonialism, 1937-1957 (Ithaca, NY: Cornell University Press, 1997); Robert Rodgers Korstad, Civil Rights Unionism: Tobacco Workers and the Struggle for Democracy in the Mid-Twentieth-Century South (Chapel Hill: University of North Carolina Press, 2003). 
which could be fixed on an individual level, thus dislocating race from polity, the only forms of racism that were condemned in the public sphere were those that took undeniably tangible or extremely violent forms. If the typical understanding of white racism holds that racist whites fixate on the threat of blackness to the point of psychological defectiveness, Mills instead argues that whites could accrue resources and cement their social legitimacy not by denigrating blacks, but rather by ignoring them altogether. Crucially, Mills argues that white ignorance is a structural, shared phenomenon which exceeds an individual's lack of access to stable knowledge. Equally importantly, he notes that ignorance does not equate to naivety or innocence; it does not absolve white Americans of agency or complicity in the racialized social system. ${ }^{7}$ White ignorance is its own complex ideological apparatus which, I argue, was deeply rooted in the material base of postwar urban politics, and which we can observe vividly through the phenomenon of cleanups and the more general pursuit of urban order and hygiene. Cleanups were fuelled by and constitutive of white ignorance. Their leaders assured Angelenos that with enough communal gumption, any derelict environment could be fixed. Not only did this framework bear few solutions for black and Mexican communities whose problems far exceeded a need for beautification, but cleanups' affirmation of individual power underwrote hostility towards potential largescale remedies, including social programmes such as public housing. The pursuit of order, furthermore, would drive an ethos of carceralism which endangered black and Mexican Angelenos. Through cleanups, white communities developed folk knowledge of how cities worked, and used their social capital to propel that knowledge into municipal politics. ${ }^{8}$ Actively ignorant of its racialized outcome, they framed their activism as pursuing normatively positive and colour-blind goals.

7 Charles Mills, "Liberalism and the Racial State," in Moon-Kie Jung, João Helion Costa Vargas, and Eduardo Bonilla-Silva, State of White Supremacy: Racism, Governance, and the United States (Stanford, CA: Stanford University Press, 201 I), 27-46, esp. 27-30, 35-45; Mills, Black Rights/White Wrongs: The Critique of Racial Liberalism (Oxford: Oxford University Press, 2017), xvi, 28-36, 57-58. In Marilyn Frye's words, ignorance is not "a simple lack, absence, or emptiness, and it is not a passive state." Marilyn Frye, The Politics of Reality: Essays in Feminist Theory (Trumansburg, NY: Crossing Press, 1983), I I8. My structural approach to race is equally indebted to the work of Eduardo BonillaSilva: Eduardo Bonilla-Silva, "Rethinking Racism: Toward a Structural Interpretation," American Sociological Review, 62, 3 (June 1997), 465-80, esp. 474.

${ }^{8}$ I borrow the term "folk knowledge" from cultural anthropology, to define knowledge acquired by peoples about man's nature and his place in the world. People are not always able to express why they hold this knowledge, as it is developed and entertained in everyday culture. Leading folklorist Alan Dundes can shed further light on this definition. Alan Dundes, "Folk Ideas as Units of Worldview," Journal of American Folklore, 84, 33 I (Spring 1971), 93-103. 
Centring ignorance diverges from the prevailing approach to the study of race in the postwar period. Historians have chiefly focused on racial interfaces, where competition between groups was direct and highly visible, and engaged explicit conflicts over resources, as in cases such as busing and housing segregation. ${ }^{9}$ While many such studies are landmarks in American history, a consequence of their dominance within the field is that racism has tended only to be recognized and analysed when at its most blatant and concrete. Kevin Kruse's history of white flight, for example, demonstrates the racism of Atlanta's white suburbanites by finding earlier instances in their lives when they interacted negatively with other races, leading them to move from multiracial urban quarters to white suburbs. Kruse argues that in all-white suburbs, "with no other colors in sight and no other classes in contention," claims to colour-blindness and class harmony can easily pass as "plausible," and thus recommends that historians focus on more explicit forms of racism. ${ }^{10}$ This prescription abdicates problematizing the challenging visibility of racial-break politics and accepting their illegibility, rather than devising new epistemic approaches suited to the study of white spaces and groups. To Kruse's credit, his refusal to invest in more theoretically involved models avoids the pitfall of scholarship on race which focusses too exclusively on language, discourse, and symbols. ${ }^{1 \text { I }}$ While well-intended in their attempts to decipher the ways in which racism can be coded, these studies often lapse into what Charisse Burden-Stelley terms "culturalism," a failure to engage seriously with political economy, thus producing an "incomplete challenge" to white supremacy. ${ }^{12}$ Cleanups present an

9 Influential examples of this large body of work include Thomas J. Sugrue, The Origins of the Urban Crisis: Race and Inequality in Postwar Detroit (Princeton, NJ: Princeton University Press, 2014); Arnold R. Hirsch, Making the Second Ghetto: Race and Housing in Chicago, 1940-1960 (Chicago: The University of Chicago Press, 1998); Matthew D. Lassiter, The Silent Majority: Suburban Politics in the Sunbelt South (Princeton, NJ: Princeton University Press, 2006).

10 Kevin Michael Kruse, White Flight: Atlanta and the Making of Modern Conservatism (Princeton, NJ: Princeton University Press, 2005), I I.

${ }^{\prime}$ Shayla C. Nunnally and Sondra Myers, Trust in Black America: Race, Discrimination, and Politics (New York: New York University Press, 20 I 2); Melanie E. L. Bush, Everyday Forms of Whiteness: Understanding Race in a "Post-racial" World (Lanham, MD: Rowman \& Littlefield, 201 I); Wini Breines, Young, White, and Miserable: Growing Up Female in the Fifties (Chicago: The University of Chicago Press, 200 I).

12 Charisse Burden-Stelly, "The Modern Capitalist State and the Black Challenge: Culturalism and the Elision of Political Economy," doctoral dissertation, UC Berkeley, 2016, 23. Although Burden-Stelly focusses on black studies, whiteness studies' culturalism has been criticized by sociologist Margaret Anderson and historian Eric Arnesen. Margaret L. Andersen, "Whitewashing Race: A Critical Perspective on Whiteness," in Ashley W. Doane and Eduardo Bonilla-Silva, White Out: The Continuing Significance of Racism (New York: Routledge, 2003), 21-35; Eric Arnesen, "Whiteness and the Historians' Imagination" International Labor and Working-Class History, 60 (Fall 2001), $3-32$. 
opportunity to analyse postwar racism both through its relation to material urban politics, and through the superstructural sense of innocence it fostered among white Americans.

I will first offer a brief overview of postwar Los Angeles's racialized geographies of hygiene, in order to establish the material context of cleanups. Then, after outlining the performative nature of cleanups, I will discuss how three groups used them to make claims to urban governance which rarely engaged with race explicitly, but which reified frameworks hospitable only to white property owners and corporations. I will then discuss how key themes of cleanups endorsed a form of carceral politics pre-dating neoliberal urbanism, thus providing one response to Andrew Diamond and Thomas Sugrue's recent call for more scholarship to excavate the roots of neoliberal urbanism in New Deal and mid-century urban policy. ${ }^{13}$

\section{AMERICA'S WHITE SPOT: PROPERTY, RACE, AND SEGREGATION IN LOS ANGELES}

During the postwar period, Los Angeles reinforced forms of segregation which opened clean and healthful spaces to white Americans and kept other races in downwardly mobile quarters marked by high rates of municipal neglect and decay. Although Los Angeles had featured unusually high rates of black homeownership in the I900s, the increasing popularity of restrictive covenants in the I920s resulted in stark racial segregation: by the early I930s, the terrain of black Los Angeles had abruptly shrunk, and 70 percent of all black Angelenos resided in one assembly district in Southwest Los Angeles. ${ }^{14}$ The

${ }^{13}$ Andrew J. Diamond and Thomas Sugrue, "Historicizing the Neoliberal Metropolis," in Diamond and Sugrue, eds., Neoliberal Cities: The Remaking of Postwar Urban America (New York: New York University Press, 2020), I-I3. 2. In doing so, Diamond and Sugrue intervened in wider debates animating studies of neoliberalism, which attempt to discern, in Jamie Peck's words, neoliberalism's "tangled prehistories." Mary Patillo and Donna Murch's contributions are particularly oriented towards identifying such continuities, connecting the racism and capitalism of the New Deal and the Great Society to neoliberal outcomes. In doing so, the collection stands in contrast with earlier urban histories which have argued for a stark divide in governance pre- and post-neoliberalism, such as Timothy Weaver's history of Philadelphia. Jamie Peck, Constructions of Neoliberal Reason (Oxford: Oxford University Press, 2010), 5; Timothy P. R. Weaver, Blazing the Neoliberal Trail: Urban Political Development in the United States and the United Kingdom (Philadelphia: University of Pennsylvania Press, 2016), I I.

${ }^{14}$ John H. M. Laslett, "Historical Perspectives: Immigration and the Rise of a Distinctive Urban Region, 1900-1970," in Roger Waldinger and Mehdi Bozorgmehr (eds.), Ethnic Los Angeles (New York: Russell Sage Foundation, 1996), 40-52. Mark Wild, Street Meeting: Multiethnic Neighborhoods in Early Twentieth-Century Los Angeles (Berkeley: University of California Press, 2005), 31; Susan Anderson, "A City Called Heaven: Black Enchantment and Despair in Los Angeles," in Allen J. Scott and Edward W. Soja, 
Second World War increased the pressure. Some r.5 million in-migrants landed in the Golden State, incentivized by abundant military jobs, and as the black population of Los Angeles nearly doubled during the war years, growing from 67,000 to 125,000 , they were met with constant discrimination in both employment and housing. ${ }^{15}$ As early as 1940, black Angelenos were confined to 5 percent of the city's area, predominantly in the neighbourhood of Watts, where they often crowded into garages, windowless storage rooms, and other increasingly small spaces. ${ }^{16}$

White Angelenos found housing in all-white towns and suburbs such as Pasadena, Beverly Hills, and Palos Verdes, and also in the burgeoning and segregated subdivisions of the San Fernando Valley, in northern Los Angeles. By I950, the Valley housed 31 I,016 residents, representing is percent of Los Angeles's total population. Only 2,593 of them were black, a mere I.5 percent of the city's black community. ${ }^{17}$ As in the rest of the nation, these white areas were financially served by federal programmes such as the Federal Housing Administration (FHA), which made homeownership attainable for millions of white Americans. ${ }^{18}$ These mechanisms were notoriously racially exclusionary: between 1932 and 1964 , less than 2 percent of FHAinsured housing was available to Americans who were not white. ${ }^{19}$ As national rates of homeownership increased by 50 percent between 1945 and 1950 alone, white Americans distanced themselves from their ethnic identities and developed a cohesive racial identity as people of property, building on a long heritage of colonial practice which attributed a white monopoly on acquisition and

eds., The City: Los Angeles and Urban Theory at the End of the Twentieth Century (Berkeley: University of California Press, 1996), 336-65, esp. 343.

is Arthur C. Verge, "The Impact of the Second World War on Los Angeles," Pacific Historical Review, 63, 3 (Aug. 1994), 289-3 I 4, esp. 30 I; Greg Hise, Magnetic Los Angeles: Planning the Twentieth-Century Metropolis (London: Johns Hopkins University Press, 1997), I 52.

${ }^{16}$ Keith E. Collins, Black Los Angeles: The Maturing of the Ghetto, I940-I95o (Saratoga, NY: Century Twenty One, 1980), 26.

17 California State University - Northridge (hereafter CSUN), URB/MM, Box 3, Folder 7, "Population and Housing in Los Angeles County: A Study in the Growth of Residential Segregation," March 1963; URB/ACCSFV, Box 7, Folder 5, "Destination 90," 1966. URB/VICA, Box 13, Folder 2, "Population Growth by Statistical Areas-City of Los Angeles, 1930 to $1961, "$ I 962.

${ }^{18}$ George J. Sánchez, “'What's Good for Boyle Heights Is Good for the Jews': Creating Multiracialism on the Eastside during the 1950s," American Quarterly, 56, 3 (Sept. 2004), 633-6I, esp. 637; Laura Pulido, "Environmental Racism and Urban Development," in Jennifer Wolch, Manuel Pastor, and Peter Dreier, eds., Up against the Sprawl: Public Policy and the Making of Southern California (Minneapolis: University of Minnesota Press, 2004), 71-99, esp. 85.

19 Dianne Suzette Harris, Little White Houses: How the Postwar Home Constructed Race in America (Minneapolis: University of Minnesota Press, 2013), 34. 
enlightenment. ${ }^{20}$ The situation in Los Angeles was not unique: in Chicago and Detroit, black population booms were met with a dearth of affordable housing and intense spatial segregation. ${ }^{21}$ It is on this highly segregated terrain that urbanites, and in this case Angelenos, elaborated their ideas of urban citizenship.

As white spaces were actively created, black spaces were under constant threat. Lacking in investment and legal protection, they featured adverse health and infrastructural conditions. During the Second World War, black Angelenos moved into Little Tokyo in the wake of Japanese removal into concentration camps. The Eagle, a black newspaper, described Little Tokyo as a "rancid, rat-infested area," "reeking with filth and dilapidation." ${ }^{22}$ By 1946, rat infestations in South Central caused rates of typhus unseen since $1924 .^{23}$ In Avalon, one such neighbourhood, nearby chemical companies and foodprocessing plants regularly released industrial debris and runoff into the streets. ${ }^{24}$ Black spaces and lives were clearly seen as disposable: in Watts, calls by black community leaders on public officials to enforce zoning laws in the face of uncontrolled building of warehouses and junkyards, creating recurrent rat and cockroach infestations, met silence. ${ }^{25}$ The only solution that interested the city was urban renewal, whereby a discourse of public health was mobilized to raze multiracial neighbourhoods. ${ }^{26}$ In 1945 , documents from Los Angeles's planning department designated its civic centre as "blighted," citing as equal causal factors the area's need of major repairs,

${ }^{20}$ Charles Simon-Aaron, The Atlantic Slave Trade: Empire, Enlightenment, and the Cult of the Unthinking Negro (Lewiston, NY: Edwin Mellen Press, 2008); Sianne Ngai, Ugly Feelings (Cambridge, MA: Harvard University Press, 2005), 91; Landon Y. Jones, Great Expectations: America and the Baby Boom Generation (New York: Random House, 1981), 43-44. Matthew Frye Jacobson, Whiteness of a Different Color: European Immigrants and the Alchemy of Race (Cambridge, MA: Harvard University Press, 1998); Harris; David Roediger, Working toward Whiteness: How America's Immigrants Became White (New York: Basic Books, 2005). Chapter 6 of Roediger's work focusses on the whitening effect of private property.

${ }^{21}$ Gregory D. Squires, Chicago: Race, Class, and the Response to Urban Decline (Philadelphia, PA: Temple University Press, 1987), 107; Joe T. Darden, Detroit: Race and Uneven Development (Philadelphia, PA: Temple University Press, 1987), 87-88.

${ }^{22}$ Scott Kurashige, The Shifting Grounds of Race: Black and Japanese Americans in the Making of Multiethnic Los Angeles (Princeton, NJ: Princeton University Press, 2008), I6 I.

23 "Residents Urged to Combat Rat Invasion," California Eagle, I4 Nov. 1946, 5.

${ }^{24}$ Josh Sides, L.A. City Limits: African American Los Angeles from the Great Depression to the Present (Berkeley: University of California Press, 2003), i I 3.

${ }^{25}$ Keith E. Collins, Black Los Angeles: The Maturing of the Ghetto, 1940-195o (Saratoga, CA: Century Twenty One Pub., 1980), 69-72.

${ }^{26}$ Norman Klein, The History of Forgetting: Los Angeles and The Erasure of Memory (London: Verso, I 997); Eric Avila, White Flight in the Age of Popular Culture (Berkeley: University of California Press, 2004). 
lack of sanitary facilities, and high proportions of "nonwhite" residents. ${ }^{27}$ The black community was well aware of this double bind of what Hillary Jenks describes as a "combination of coercive attention and not-so-benign neglect." ${ }_{28}$ In 1963, an exasperated Eagle article deplored a fire at an abandoned gas station on South Central Avenue, caused by a pile-up of old tires and rubble. Listing past efforts to spur city officers to action, the Eagle wearily noted, "It is not that the authorities don't know about these conditions, but they seem to work very, very slowly in doing anything about them." And, in a fatigued tone that indicates a high degree of familiarity with this process, the article further predicted that the fire would attract the attention of city planners who would label the area "gray" or "blighted," and that "we, the oppressed minorities become the dispossessed minorities . . . forced to move into other 'gray' areas because the "white' areas are closed to us." 29

Cleanups exhibited very little understanding that racial segregation and neglect explained the state of black Los Angeles. Instead, cleanup leaders exemplified an observation that two anthropologists have made on the subject of public health, where they attributed a disproportionate amount of blame to individual acts of incivility, neglecting the structural roots of poor sanitation, and thus confused the relationship between "power and individual selfcontrol." 30 Significantly, however, very few cleanup leaders used those occasions to denounce or defame black or Mexican Angelenos as lacking in discipline, as might be expected given Los Angeles's racial geographies of order. Rather, cleanups were used to exalt the white self as able to reform and make place, usually opposing this agenda to the state. Cleanups encouraged white Angelenos to believe that individual behaviour and free-market solutions made successful cities, and acted as spectacles of white ignorance which sought to entrench a system suited only to the will, priorities, and capacities of white property owners.

\section{“THIS IS A DRIVE!”: OPTIMISM, PROMOTION, AND ANTISTATISM IN MID-CENTURY CLEANUPS}

Throughout the mid-century period, cleanups sparked into operation from a feedback loop of residents, civic clubs, and the media. Periodically, a burst of

${ }_{27}$ CSUN, URB/CRC 5, Box I 17, Folder 4 "Housing Study: City of Los Angeles," I 945.

${ }^{28}$ Hillary Jenks, "Bronzeville, Little Tokyo, and the Unstable Geography of Race in PostWorld War II Los Angeles," Southern California Quarterly, 93, 2 (Summer 201 I), $201-$ 35, esp. 208.

29 "Fire Hits Dump Site, Eyesore on Central," California Eagle, i 4 March 1963, I.

${ }^{30}$ Philippe Bourgois and Jeffrey Schonberg, Righteous Dopefiend (Berkeley: University of California Press, 2009), 136. 
indignation would emanate from one of these parties and beget a short, intense, voluntary cleanup, most extensively during the years 1947, 1952, and $1954 .{ }^{3 \mathrm{I}}$ To publicize their educative messaging, cleanups took on spectacular proportions. Many cleanups involved "broom brigades" which mimicked military marches, or parades, in which local figureheads proudly rode some of the city's cleaning machines. Some cleanups enlisted the help of local beauty queens, elected "Queens of Clean" in local competitions between suburbs and neighbourhoods, or recruited movie stars such as Ann Blyth to popularize the event and lend it a touch of glamour. ${ }^{32}$ The organizers of cleanups were never short of gimmicks: on one occasion, a Tasmanian kangaroo was flown in from San Diego to serve as a cleanup mascot called Parky. A contest to write a Parky theme song promised a trip to Europe as a grand prize. ${ }^{33}$ As Karal Ann Marling has noted, the postwar era was marked by a striking visual culture, as a national obsession with the shiny and glittery took hold over food, clothing, and home design. ${ }^{34}$ Cleanups tapped into this interest, deploying artistic capabilities to rouse public excitement over cleanliness. For a I 959 cleanup, the North Hollywood Junior Women's Club bejewelled a trash can and broom, displaying them in local store windows to advertise the coming event. ${ }^{35}$ The previous year, the Pacoima Women's Club had demonstrated in the streets for cleanup awareness, archly wearing mops on their heads, with one sign reading "Help Add 'G' to Litter." ${ }^{6}$ Cleanups were thus highly performative occasions, which served to spectacularize the actions of

31 "Civic Leaders Support Drive to Clean Up in Los Angeles: C. of C. Reminders Sent to ı 00,000 as Women Lend Help," Los Angeles Times, Io Sept. I947, I; "Mayor Proclaims Gigantic Spring Cleaning Campaign: April and May Designated for Litter Drive," Los Angeles Times, I April 1954, 2; "South San Gabriel Will Launch Cleanup Drive," Los Angeles Times, 8 April 1956, I; "Home Clean-Up Drive Launched in Azusa," Los Angeles Times, 8 April 1956, I; "Cleanup Drive Launched by Atwater Chamber," Los Angeles Times, 24 June 1956, I; "Litter Rivals Smog as Blot on City: Parky, the Tidy Kangaroo, Cuts Park Trash by 50\%, But Angelinos Blush over Streets," Los Angeles Times, 24 Sept. 1956, 2.

32 "Glendale Gets Face Lifting; Mayor Helps," Los Angeles Times, 19 April 1955, I3; "New Fresno Mayor Orders Vice Crackdown," Los Angeles Times, 30 April 1957, 24; "Redondo C of C Backs Annual Cleanup Drive," Los Angeles Times, ro Aug. 1958, I; "Miracle Mile Cleanup Cited by Executives," Los Angeles Times, 7 May 1959, I. "Toluca Lake Faces Cleanup," Valley Times, I961.

33 "Real Kangaroo Kicks Off Campaign against Litter: Service Station Gives Out Paper Bags to Motorists and Porky Is There to Help," Los Angeles Times, 27 Nov. 1956, I; "Prizes Announced for Parky Song Contest: Top Award for Theme Tune in Cleanup Drive Will Be Trip to Europe over Polar Route," Los Angeles Times, 20 Jan. 1955, I.

${ }^{34}$ Karal Ann Marling, As Seen on TV: The Visual Culture of Everyday Life in the Igsos (Cambridge, MA: Harvard University Press, I 994).

35 "North Hollywood Plans Litter Cleanup Day," Los Angeles Times, 8 March 1959, I-sf3.

36 "Pacoimans March in Cleanup Campaign," Los Angeles Times, 19 Oct. 1958, I. 
a select few in cleaning a city that was seen as falling into disrepair. Devolving sanitation to the level of individual behaviour entailed that the scope of cleanups was largely inadequate. Letters published in the Los Angeles Times accused voluntary street sweepers of routinely shoving garbage into storm drains instead of collecting it, and bemoaned cleanups' short lifespan in public attention. The Times itself, a year after Bassett's exposé, had to admit that Los Angeles was just as dirty as in 1946. Anecdotes of amateurish behaviour were common. A notable misfire occurred when a cleanup targeting rats indirectly brought about a mite infestation, as mites jumped from rat to resident. ${ }^{37}$ To focus on the material efficacy of these cleanups, however, would be to miss their deeper motivation: they remained a popular activity not because they produced dramatic physical effects, but because they affirmed an understanding of urban citizenship wherein white property owners were cast as the guardians of the city.

Cleanup movements, it should be underlined, were not monolithic. Highlighting their variegated leadership composition, further, will allow me to highlight how different classed and political objectives could beget the same racial agenda. I will delineate three major groups, and their relation to race, urbanism, and ignorance. The first group was composed of elite women from the powerful Los Angeles Chamber of Commerce. This formation, I argue, used cleanups to make Los Angeles attractive for wide-scale industrial and commercial investment. Downtown space was thus only legible for its monetary value. The second cluster, located in the San Fernando Valley, featured white suburbanites who propagated a message of self-reliance, enshrining individual habit as able to resolve large-scale problems. A third group took such a message to its extreme, using cleanups to protest federal housing projects. An existing body of scholarship has ascribed paranoid impulses to suburban Angelenos in particular, portraying them as beset with anguish at the havoc caused by derelict multiracial areas on the body of the city. ${ }^{38}$ Yet such a sense of racial dread only partially describes these organizations, which were guided far more visibly by a sense of racially blinkered optimism and faith in social engineering typical of the postwar era. ${ }^{39}$ Indeed, the

37 "Employing Reason as Our Weapon," Los Angeles Times, I7 Feb. 1947, I; "Fire Chief Named Building Inspector, for Buena Park," Los Angeles Times, 2 I April 1953, 25; "Letter to the Times: In Old Picture," Los Angeles Times, 28 March 1954, I. "City Still Unkempt after Long Drive: Resurvey by "Times" Cameramen Shows Areas Again Debris-Ridden," Los Angeles Times, 7 Sept. 1947, I.

${ }^{38}$ Klein, The History of Forgetting, I I; Avila, White Flight, 97; Mike Davis, City Of Quartz (London: Verso, 2006), I 53-54.

39 Greg Eghigian, Andreas Killen, and Christine Leuenberger, "Introduction," in Eghigian, Killen, and Leuenberger, eds., The Self as Project: Politics and the Human Sciences (Chicago: University of Chicago Press, 2007), 2-8. 
first group barely acknowledged other people, let alone races, focussing on profitability instead. Valleyites almost never mentioned downtown Los Angeles, and typically eschewed overt expressions of racism which would have challenged black Los Angeles by unfavourably comparing it to the white Valley. Cleanup leaders, in many cases, believed all urbanites could remake a more successful city, and seemed to think of their solutions as universal by failing to acknowledge their particularity. Their activism either had no concern for the welfare of black and poor Angelenos, or actively rejected programmes that could deliver improvement for these populations, on the basis of combating state overreach and upholding community pride. Rare interactions with black and brown Angelenos, as we will see, changed little: white Angelenos developed a dense interpretive framework of successful urbanism, and advocated for it even in the face of stark contrary evidence. To borrow from feminist philosophers of ignorance, their activism led them to act as "arrogant perceivers," using their own experiences as an authoritative lens through which to judge the realities of other races and classes, even as they ignored their needs. ${ }^{40}$

As Sarah Elkind notes in her history of the Los Angeles Chamber of Commerce, this powerful interest group had extensive sway over regional policy and public opinion, its influence even reaching federal decision-making processes. ${ }^{4 \mathrm{I}}$ The white elites spearheading its cleanups had a clear agenda: to make the city more beautiful so that it would be more profitable. Those cleanups treated black and Mexican Angelenos as essentially invisible, incidentally located on parcels of land that could be put to productive use. High-society Angelenos, mostly women, led cleanups. Their figurehead, Valley Knudsen, was a fixture of Los Angeles's civic leadership, having founded the Los Angeles Chamber's Women's Division and a profitable creamery business alongside her husband. Knudsen was a local celebrity: Lady Bird Johnson credited Knudsen's work as her inspiration in launching her own beautification programme as first lady. Knudsen clearly embraced a mercantile view of urban space, using as her personal motto "Beauty is Good Business. Beauty is Good Investment." ${ }_{42}$ Her

${ }^{40}$ Mariana Ortega, "Being Lovingly, Knowingly Ignorant: White Feminism and Women of Color," Hypatia, 21, 3 (Summer 2006), 56-74, esp. 59; Maria Lugones, Pilgrimages/ Peregrinajes: Theorizing Coalition against Multiple Oppressions (Lanham, MD: Rowman \& Littlefield, 2003).

${ }^{41}$ Sarah S. Elkind, How Local Politics Shape Federal Policy: Business, Power, and the Environment in Twentieth-Century Los Angeles (Chapel Hill: University of North Carolina Press, 20 I I), I-4.

42 Eric Warren, Eagle Rock: 19II-20II (Mount Pleasant, CA: Arcadia Publishing, 201 I), I7; "Mrs. Valley Knudsen," Los Angeles Times, i I Sept. I976, oc I; "Ceremony Honors Valley Knudsen," Los Angeles Times, 2 I Feb. I971, h6; "Valley Knudsen Spearheads New Effort of 'Los Angeles Beautiful'," Christian Science Monitor, 19 Feb. 1962, 4. 
close collaborators had comparable experience in business or politics. Jessie Moffett had been the president of the Southern California Chapter of the American Market Association, and the president of the Los Angeles Advertising Club, and had consulted for researchers in public administration at the University of Southern California. ${ }^{43}$ Virginia Baldwin sat on the board of a dozen state-wide horticultural or beautification societies. ${ }^{44}$ Lola Jaques was a well-respected socialite, and a one-time president of the Opera Reading Club of Hollywood.45 Rose Navarro had cut her teeth in the Property Owners League, where she had led anti-rent-control demonstrations in $1950 .{ }^{46}$

These women worked through a taskforce named Los Angeles Beautiful (LAB), founded in 1949 and funded by private donations, with the explicit objective to target what it called "dinginess in the city's downtown area." 47 When it came to cleanups, LAB's were the largest in the region, affiliating as many as a thousand volunteers at once. Its programme to prompt housewives to report illegal dumping gathered five thousand participants. ${ }^{48} \mathrm{LAB}$ endorsed a host of beautification projects, organizing gardening contests in eighty-three municipal schools, running competitions for beautified buildings, and working with downtown merchants such as the Textile Association of Los Angeles for large urban reforestation programmes, planting 250,000 trees in Los Angeles between 1955 and $1965 .{ }^{49} \mathrm{LAB}$ had mass reach thanks to the connections of the Los Angeles chamber: the powerful real-estate developer Fritz Burns sat on LAB's board, and national industrialists ran fund-raisers for its efforts. ${ }^{\circ}$

43 “Auto Dealers Promote Service in Radio Drive," Broadcasting, Broadcast Advertising, i 9 Jan. I942, 37; Philip Joseph Schlessinger, "Attitudes toward Supervision in Civil Service," dissertation, University of Southern California, 1943, 2; "Tourist Plan Wins Award," Evening Vanguard, 7 Feb. 1949, 2; "Sigma Kappas," Los Angeles Evening Citizen News, 23 Nov. 1962, 4.

44 "Plant-a-Tree Week Observance Slated," Van Nuys News, 25 Feb. 1965, 109; "Article 4," Los Angeles Times, I 2 March I972, KI 4.

45 "Air Corps Officer Weds Miss Jaques, Tri-Delt," Citizen News, i 8 Aug. I94 I, I I.

46 "Losing Freedom by Default," Los Angeles Times, 22 Sept. 1950, A4; "Landlords Hold Another Street Protest on Rent', Los Angeles Times, 2 I Oct. 1950, I; "Nomination of City Beautifiers Sought," Los Angeles Times, 24 Aug. 1958, B3.

47 "Los Angeles Beautiful Restoring Civic Pride," Los Angeles Times, 5 Aug. 1962, G7.

48 "Los Angeles Beautiful Fund Slated," Los Angeles Times, ro Oct. I957, B I.

49 "Los Angeles Beautiful Hailed for Progress," Los Angeles Times, I 4 Oct. I959, BI; "Los Angeles Beautiful," Los Angeles Times, 25 March 1965, A4; "40 Awards Presented by Los Angeles Beautiful," Los Angeles Times, I9 June 1963, A8; "Los Angeles Beautiful Group Reviews Activity," Los Angeles Times, 14 June 1955, AI; "Youth Lends a Helping Hand," Los Angeles Times, 5 Dec. 1954, M58; "Los Angeles Beautiful Presents 40 Awards," Los Angeles Times, Io Oct. 1957, BI; "Los Angeles Beautiful Fund Slated'," Los Angeles Times, io Oct. 1957, B I.

so "Los Angeles Beautiful Group Named," Los Angeles Times, I 5 Sept. I 955, Ar; "Los Angeles Beautiful Fund Slated," Los Angeles Times, ro Oct. 1957, B r. 
Corporate bodies were likely to support LAB for economic reasons. Keeping Los Angeles's reputation pristine was, for example, essential for its tourism industry. In 1957, Walter Braunschweiger, executive vice president of Bank of America, spoke to LAB in these terms, explaining that the previous year, 3.5 million tourists had spent $\$ 600$ million dollars in downtown Los Angeles, motivating him to further salvage its perceived disorder and increase the area's moneymaking potential. ${ }^{51}$ During an award dinner that same year, Harold Quinton, board chairman of Southern California Edison Co., told the guests that derelict communities are blighted "with an ugliness that will cost millions to eradicate." ${ }_{52}$

This kind of focus on economics made LAB unable to generate or centre concern for the black and Mexican community of Los Angeles. In fact, LAB found itself playing a central role in boosting aforementioned urban renewal programmes which displaced the black community, treating the consequences of segregation and disinvestment as a threat to Los Angeles's potential as a world city. LAB regularly met with the Community Redevelopment Agency, the body in charge of urban renewal in Los Angeles, and was consulted to make sure its redevelopment plans sufficiently incorporated beauty and nature. ${ }^{53}$ Further, LAB's rare attempts to cooperate with multiracial groups were fraught with condescension. A mass 1965 blackled cleanup of Central Avenue featured beautification efforts, but also guidance on health care, retirement, home loans, and a vaccination drive. Despite its ample funds, LAB only provided paint for three houses, which, it specified, needed to be in good shape, and belong to owners who pledged to keep up their property thereafter. ${ }^{54}$ In 1970 LAB asked the city's Housing and Urban Development Agency for funds to beautify five multiple dwellings in City Terrace. Virginia Baldwin stated that this area was chosen as a "low income area" with many people on "welfare," almost all of them Mexican. Though Baldwin worried about the absentee landlords, she peppily insisted that renovation was "feasible" with "minimal expenditures" if residents worked to achieve their goals. 55

LAB's large-scale vision for Los Angeles meant it was friendlier to municipal government than other cleanup groups. In one speech, Knudsen praised the "unparalleled co-operation" of city and county in making LAB meet their

51 "Beautified City Urged to Attract Tourist Trade," Los Angeles Times, i7 Sept. 1957, 16.

52 "Los Angeles Beautiful Presents 40 Awards," Los Angeles Times, io Oct. 1957, B I.

53 "Litter Bad Drive Plan Finds Widespread Favor," Los Angeles Times, 9 July 1957, B3.

${ }^{54}$ The Huntington Library, San Marino, California, mssHahn, Box 52 I, Folder iB, "News Release," 7 June 1965; "News Release," I 8 June 1965.

ss "U.S. Funds Asked to Begin Rehabilitation of East Side Homes," Los Angeles Times, I 3 Feb. I970, SGI. 
objectives. ${ }^{56}$ However, Baldwin's belief in individual gumption reflects the broader antistatist politics of cleanups. In the San Fernando Valley, indeed, cleanups were chiefly a way of affirming the pride of suburban homeowners in their self-reliance. Valleyites came from somewhat less prestigious ranks, even though they could still be described as affluent or middle-class. Alvin Kleeb, who acted as president of the Granada Hills Rotary Club, was a jeweller. ${ }^{57}$ Bernard Herzog was a public accountant. ${ }^{58}$ Women involved in cleanups were traditionally housewives who have left little biographical information in historical records, beyond their investment in various civic initiatives. Valley cleanups were certainly inspired by LAB: initiatives like the Reseda Beautification Committee patterned their operations after the work of $\mathrm{LAB}$, and $\mathrm{LAB}$ leaders regularly visited the Valley to congratulate them on their programmes. 59 However, Valley organizations tended to use cleanups not for reasons of profit, but to advocate for social models based around individual action and rollback of the state. The Valley had little to no interest in promoting tourism or corporate sponsorship: their concern was one of self-image.

Valley cleanups were distinctly local, and relied on churches, storeowners, and women's clubs. ${ }^{60}$ Cleanups were often a part of local celebrations, with festivities like the Woodland Hills Fall Fiesta, Canoga Park street dances, and the Catalpa Festival either preceded by a cleanup or serving to advertise an upcoming one. ${ }^{61}$ Cleanups themselves could be the main event. In 1953 , a Granada Hills cleanup was so lavishly presented that it was described by chamber of commerce chairman Alvin Kleeb as a "gala broomstick parade." ${ }_{22}$ In one sense, cleanups served to affirm shared local values and

56 "Los Angeles Beautiful Hailed for Progress," Los Angeles Times, I 4 Oct. 1959, B I.

57 "Granada Rotarians Will Hold Forums," Van Nuys News and Valley Green Sheet, 5 April 1959, 31; "Alvin Kleeb Will Speak on Watches at Reseda Rotary," Van Nuys News and Valley Green Sheet, I 4 Nov. 1949, I 3.

58 "Bernard Herzog, CPA, Opens New Office," Los Angeles Evening Citizen News, io March I 949, I 3.

59 “Reseda Unit Pushes L.A. Beauty Plan', Valley Times, 25 Nov. 1960, 8; "Valley Beautiful Group Organized," Valley Times, 25 July 1958, 2.

60 "Pastors Asked to Aid in V.N. Cleanup Drive," Valley Times, 2 April 1948, 6; "New Refuse Bins Placed in North Hollywood," Valley Times, 7 April 1948, 3; "Junior C. of C. Backs Cleanup Drive in V.N.," Valley Times, I5 March 1948, 5; "Clean-Up Drive Gets under Way April 22," Valley Times, I 3 April I946, I I.

61 "Woodland Hills in Anti-litter Drive," Valley Times, 20 Sept. 1957, 3; "Civic Groups Lend Hand in Clean-Up," Valley Times, 2 Dec. 1946, i I; CSUN, URB/CPWC, Box 7, Folder 2, "Catalpa Fete," The News, I May i947; "Orcutt Park Scene of Barbecue," Canoga Park Tribune, 2 May 1947; “'Gran Baile' in Woman's Clubhouse," Canoga Park Tribune, 2 May 1947; CSUN, URB/CPWC, Box 7, Folder 2, "Spring Flower Festival Set for May Ist", Canoga Park Herald, 2 Jan. I947; "Plan to Make Canoga Park 'Beautiful'," Valley Times, 5 Nov. 1946, 3.

62 "Granada Hills Sets Clean-Up," Valley Times, 22 Sept. 1953, I I. 
identity. As one Valley Times piece put it, cleanups were a way for new and old residents to say "howdy" to each other. ${ }^{63}$ Denouncing litterers was done with levity and humour to nudge community members into participation: a Burbank Cleanup week chose as a mascot a local donkey named John, draping him in a sign that read, "I will not clean-up, paint up, fix up ... and you know what I am!" 64 But Valleyites were more than just clean: their cleanliness affirmed their ability to make place. The tone of cleanup advertisement was commanding in its belief in the power of sheer will. One Valley Times editorial called for Valleyites to "make every town in the Valley a spotless town and keep it that way," while Mrs. Ben Gotter, a local civic leader, stated of a 1955 drive she managed, "we've decided, and we're just beginning to work. This is a drive!"6s In one Reseda cleanup, the chairman, Bernard Herzog, said that "with the right cooperation and enthusiastic support of residents, the clean up effort will result in almost immediate improvement." ${ }^{\prime 6} 6$ Valleyites' essential faith in their own ability to make better places was constitutive of white ignorance. In affirming that all that mattered in the production of clean and healthful space was residents' desire to care for their environment, they lacked any fundamental understanding of the ways in which the postwar economy had enabled the protection of their spaces, and the neglect and destruction of others.

Valley cleanups' optimistic reading of individual capacity was often contrasted to government action, which was deemed inefficient and wasteful. Cleanups, indeed, could take on airs of taxpayers' revolts. One 1946 Valley Times piece underlined that the city cleaned up "at public expense," and thus it was fitting for property owners to invest in maintenance and upkeep. ${ }^{67}$ Cleanups could thus act as cutting critiques of municipal budgets which provided services deemed unnecessary due to the superiority of community action. One local article congratulated the Canoga Park Woman's Club for their cleanup, stating, somewhat paradoxically, that the women were sponsoring it because "they intend to demand something in return for the taxes they are paying." 68 While what these women asked from the state was left unsaid, we can deduce that cleanups could espouse a symbolic meaning of citizen can-do against big government. Throughout the postwar period,

\footnotetext{
63 "Sandy Goes Raking," Valley Times, 6 Sept. 1 946, 3.

64 "One Picture Equals I o,000 Words," Valley Times, I May I95 I, 3.

65 "Sun Valley Women in Clean-Up Drive," Valley Times, I5 Nov. 1955, I3; "Are You with Them," Valley Times, 7 April i 948, 4.

66 "Clean-Up Drive in Reseda," Valley Times, I 3 Aug. 1960, I 5.

67 "Sandy Goes Raking," Valley Times, 6 Sept. 1 946, 3.

${ }^{68}$ CSUN, URB/CPWC, Box 7, Folder I, "Community Betterment Plan," Canoga Park Herald, 17 Oct. 1946.
} 
resentment grew. A local paper described the city's lot-clearing programme as being "as costly as it is slip-shoddy," and a local lawyer, Will Chappel, argued to the North Hollywood Toastmasters Club that the city wasted $\$ 4$ million a year on street cleaning, and that "were it not for ... community cleanup drives, the city's litter problem would be even more critical." 69

As the Valley used cleanups to cast doubt on state-sponsored services writ large, some groups in the Los Angeles region employed cleanups to make a militant case against public housing programmes as well as urban renewal. The adjoining town of Pasadena, for example, launched "Operation Junkyard" in 1952. A two-year voluntary programme led by Pasadena building superintendent Walter Zuetell, Operation Junkyard involved volunteers inspecting every dwelling in Pasadena and sending information to individuals about how to rehabilitate their property, alongside a cleanup campaign. Pasadena's plan was a pointed attack on big government: indeed, its motto, "no federal funds requested or received," attacked mid-century urban renewal, with Pasadena cleaners insisting that "federal aid costs more than it's worth" and that they employed only local public servants instead of a "flock of high salaried government officials" to inspect the city's 39,657 properties. A tone of optimism also prevailed here, where "neighborhood pressure" led to spontaneous improvement, and where, of the mere ninety-six dwellings targeted for demolition, ninety households found "decent housing accommodations of their own initiative," according to a local paper. $7^{\circ}$ Zuetell prided himself on his programme being about more than "enforcement of any ordinance," but rather one of "public relations," staking the will of property owners as a structurally transformative force at the explicit expense of government aid. $^{71}$

Although Zuetell did not explicitly mention it, Pasadena was not the only city interested in using owner responsibility to deter public housing. Los Angeles officials had become increasingly interested in a similar undertaking that antedated Operation Junkyard, and which may have inspired it. In Baltimore, downtown businessmen had issued an impressive 1,500 notices to slumlords in 1950 , addressing 90 percent of these violations by 1953 . This plan was nationally known as a way to undercut public housing, earning itself the scathing criticism of Frank Zeidler, the socialist mayor of

69 "N.H. Club Meet," Valley Times, 28 Feb. 1957, 3; "Cheers for Better Cleanup Job Announced by the City Council," Valley Times, I I March I954, I 4.

70 "Pasadena Clearing Slums without Aid: 'No Federal Funds' Is Slogan of City Cleaning Up in Operation Junkyard," Los Angeles Times, 16 March 1952, I; "Pasadena Cleans House," The Tidings, 28 March 1952, I5.

${ }_{71}$ “Operation Junkyard Drives Out Substandard Housing in City," Pasadena Independent, I 7 April 1952, 34. 
Milwaukee, who rightly underlined that pointillistic improvement was no substitute for large-scale planning. ${ }^{72}$ The Pasadena plan, however, became locally famous in its own right, earning commendation from the Home Builders Institute and the Pasadena Citizen's Council for Planning, and garnering international attention as American and Canadian mayors wrote to Zuetell requesting help replicating his plan. ${ }^{73}$ Zuetell's influence swelled in Los Angeles: in I950, C. R. Drake, acting as secretary of the Monterey Woods Improvement Association, a community in North East Los Angeles, had sued the city of Los Angeles for planning to extend Rose Hill Courts in his locality. As the suit dragged on, Drake wrote in the Southwest Wave that there was no need for public housing projects in Los Angeles, citing the success of Baltimore's cleanups, which had eschewed a "socialized public housing empire," before mentioning that "our neighbor, Pasadena, is doing the same, with excellent results," arguing that "the same could be accomplished in the city of Los Angeles at a nominal cost." 74 These political factions agreed that some areas needed help: however, they believed it could be delivered through self-reliance and property-owner responsibility, values which could be marshalled through a cleanup. Indeed, in Riverside, when a contractor and an accountant sued the city for planning a thousand units of public housing, they rallied a group of residents under the banner of "Citizens Against Creeping Socialism" and made the case for a "Pasadena Plan," where beautification and a touch of rehabbing could and would supplant the need for comprehensive building programmes. ${ }^{75}$ The same argument was voiced in the Bunker Hills project in downtown Los Angeles, where anti-urban-renewal forces argued that disrepair was a matter of "poor

${ }^{72}$ Nicholas Dagen Bloom, Merchant of Illusion: James Rouse, American's Salesman of the Businessman's Utopia (Columbus: Ohio State University Press, 2005), xviii, 63-70; “Ask 'Baltimore Plan' Law to Bolster L.A. Housing," Valley Times, 16 July 1952, I; 'Baltimore Expert Advises on Slums," Valley Times, i 8 Sept. 1953, 2; "O.K Funds for Slums Project," Valley Times, 24 June i952, 2.

73 "Pasadena to Be Honored for Cleaning Up Slums," Los Angeles Times, i9 April 1953, I; "Citizen's Council Lauds City's Anti-slums Drive," Pasadena Independent, I April 1952, I3; "Operation Junkyard Drives Out Substandard Housing in City," Pasadena Independent, 17 April 1952, 34.

74 "Civil War in Los Angeles," Southwest Wave, 27 March 1952, 36. Although Drake's lawsuit was eventually dismissed, the considerable hostility to public housing in Los Angeles led to the extension's demise later in the 1950s. Josh Sides, L.A. City Limits: African American Los Angeles from the Great Depression to the Present (Berkeley: University of California Press, 2003), I 20; Don Parson, Making a Better World: Public Housing, the Red Scare, and the Direction of Modern Los Angeles (Minneapolis: University of Minnesota Press, 2005), 2, 36-37, 104, I31, I35.

75 "Drive Slated for Cleanup in Riverside: Pasadena Plan for Housing Correction Will Be Pushed," Los Angeles Times, 16 Dec. 1952, 19; "Suits Snag Riverside Housing Plan," Daily News, 9 July 1952, 2 I. 
housekeeping" and that painting and remodelling would suffice to halt the area's downturn. ${ }^{76}$ I have already outlined how the implementation of urban renewal failed the black community; however, when white Angelenos rallied to dismantle state programmes out of principle, they enshrined a view of urban order hostile to large-scale reparation, preferring to uphold owner responsibility instead, an outlook useless to communities which had been legally and fiscally disempowered from owning property. ${ }^{77}$ It is certain that cleanup activism, especially when deployed against public housing, featured some self-conscious racist elements. However, its ability to pass off a model of individual action as common sense also relied on the fact that white Angelenos had used cleanups on their own terrain as a solution to urban disorder, and had thus, in their mind, successfully developed a universally applicable alternative to urban renewal which fit their antistatist values.

\section{“GOOD HOUSEKEEPING”: CARCERALISM AND THE DOMESTIC CITY}

Beyond these specific political goals, cleanup groups relied on similar imagery to encourage Angelenos to think of the city in particular ways. Indeed, cleanups were educative vehicles, with LAB lobbying officials to deliver anti-littering lessons in municipal schools, hoping children would in turn better their parents' behaviour. ${ }^{78}$ In the Valley and downtown Los Angeles alike, when homeowners descended on their streets, they were described by newspapers as setting "an example" or providing a "demonstration" of how public space should be kept.79 This performative dimension typifies what Christopher Capozzola, in a different context, defines as "coercive voluntarism," wherein the line between

${ }^{76}$ Mara A. Marks, "Shifting Ground: The Rise and Fall of the Los Angeles Community Redevelopment Agency," Southern California Quarterly, 86, 3 (Fall 2004), 24I-90, esp. 25 I.

77 For more developed criticism of urban renewal as well as discussion of its progressive roots see Christopher Klemek, The Transatlantic Collapse of Urban Renewal: Postwar Urbanism from New York to Berlin (Chicago, The University of Chicago Press, 20 I 2), 2; Samuel Zipp, Manhattan Projects: The Rise and Fall of Urban Renewal in Cold War New York (Oxford: Oxford University Press, 2010), 25-27; Jennifer Hock, "Upper West Side Stories: Race, Liberalism, and Narratives of Urban Renewal in Postwar New York," in Robin Schuldenfrei, ed., Atomic Dwelling: Anxiety, Domesticity, and Postwar Architecture (London: Routledge, 2012), 229-39; Dennis R. Judd, City Politics: The Political Economy of Urban America (London: Routledge, 2008), I 32.

78 "Key to Clean City Seen in Education," Los Angeles Times, 25 March 1954, I I; "School Efforts to Keep City Clean Outlined," Los Angeles Times, 26 March 1954, 5; "Cleanup Projects Will Be Advanced," Los Angeles Times, I 4 April 1954, 22.

79 "Rotarians Don Jeans to Aid East L.A. Cleanup: Bankers Doctors, Businessmen and Wives Gather Trash along 10 Miles of Streets," Los Angeles Times, 25 April 1955, 2; "Pastors Asked to Aid in V.N. Cleanup Drive," Valley Times, 2 April ı948, 6. 
voluntary and forced activity was blurred, using shame and performativity to browbeat citizens into participation. ${ }^{8 \circ}$ It should be underlined that cleanups' focus on casting property owners as the true guardians of the city was disingenuous, given that the actual labour of cleanliness was chiefly undertaken by black Angelenos in sanitation work. By 1960, 95 percent of Los Angeles refuse workers, 80 percent of street maintenance workers, and 95 percent of custodians were black. ${ }^{81}$ In an ethnography of Watts, an unnamed black maid reflects, "The work was hard and I didn't really feel comfortable in an all-white neighbourhood. The only blacks that I ever saw were the gardener, the maid next door, and the garbage collectors." ${ }^{\prime 2}$ These workers, predictably, received none of the quixotic praise showered on cleanup leaders in local newspapers.

One framework cleanup leaders used to advance their objectives was the idea that public space was analogous to private space. This remapping, as I will argue, provided the basis for cleanups' alliances with carceralism. Indeed, cleanups consistently asserted that the city was at its best when it resembled a white middle-class home. A 1954 feature on urban sanitation in the Los Angeles Times advised that cities should be treated like homes, calling city areas a "sort of public living room." Frederic Chase, as president of the Los Angeles Clean City Crusade, a task force supervised by LAB, made a similar point in 1957 , arguing that "the basic idea is your city is your home-keep it as clean as you do your home." ${ }_{3}$ Cleanups were often described by Valley newspapers as "good housekeeping" or "community housekeeping." 84 Cleanup proponents insisted that domestic cleanliness would radiate outwards from homes to the city itself. In 1947, Reverend Robert Cordell came to the Canoga Park Woman's Club to laud their cleanups for "starting in the home, and extending through lawn, streets, and parkways." 85 This domestic city could be yoked to economic health, with the wives of the Van Nuys Junior Chamber of

${ }^{80}$ Christopher Capozzola, Uncle Sam Wants You: World War I and the Making of the Modern American Citizen (Oxford: Oxford University Press, 2008).

${ }^{81}$ Raphael Sonenshein, Politics in Black and White: Race and Power in Los Angeles (Princeton, NJ: Princeton University Press, 1993), 24.

82 Keith E. Collins, Black Los Angeles: The Maturing of the Ghetto, 1940-195o (Saratoga, NY: Century Twenty One, i980), 53.

83 "Tidiness is a Matter of Habit," Los Angeles Times, 4 April 1954, I; "Antilitter Theme: Keep City as Clean as Home. Keynote of Permanent Campaign Sounded by New Director of Los Angeles Crusade," Los Angeles Times, I J Jan. 1957, I.

${ }^{84}$ CSUN, URB/VICA, Box 17, Item I, "Chamber Seek Expansion of Technical Training," Van Nuys News, Jan. 1959; "Fernangeles Club," Valley Times, 24 Feb. 1956, I 4.

${ }^{85}$ CSUN, URB/CPWC, Box 7, Folder 3, "Mrs. Robert Smith New President Canoga Park Woman's Club," Canoga Park Herald, 2 Oct. 1947. 
Commerce choosing as their I 954 cleanup slogan "Good Housekeeping is Good Business." 86

This framework reflects the importance of female leadership in cleanups, as can be observed in the high-achieving board of LAB. Through cleanups, the domestic work of the housewife became analogous to large-scale community care and the preservation of economic and civic opportunities. This was accomplished in two ways: first, by instructing women that their household activities included the community. In 1946, the Women's Division of the Los Angeles Chamber of Commerce distributed 325,000 copies of a "Homemaker's Check List," which included, among private matters, a duty to keep parkways clean, and not to dump or litter. ${ }^{87}$ Second, it was argued that housewives had specific expertise to contribute to beautification and health. Coverage of a 1948 Van Nuys cleanup underlined the involvement of local women "to show what the housewife can do about keeping homes and streets spotless." ${ }^{88}$ In 1949, when a group of businesswomen surveyed downtown Los Angeles to inspect garbage disposal and collection, an article in the Los Angeles Times noted that since "housewives have learned how to save steps in housekeeping," "it may be that the women will be able to show the officials how their men and trucks can make their rounds more efficiently." Both chairs of the committee, Margaret Gorman and Mary Helen Page, were quoted as saying, "there is nothing like a woman aroused about the health of her city." 89

This type of rhetoric, whereby women used their positions as wives or mothers to foment public change, especially in the context of urban welfare, was not novel, and has been well noted by historians of the Progressive Era. ${ }^{\circ}$ However, these same scholars have also underlined that Progressive Era women, despite their paternalism, agitated against the ravages of industrial capitalism. ${ }^{91}$ In the postwar period, white women's organizations were instead geared towards antistatist objectives, in part because they identified much more

86 "JR. Chamber Wives Back V.N. Clean-Up," Valley Times, 28 May 1954, 3.

87 "Grandparents Plead in Vain for Suspect," Los Angeles Times, 20 Dec. 1946, 2.

88 "Cleanup Dust Will Fly in Van Nuys Saturday," Valley Times, I April 1948, 2.

89 "Women Plan to Make a Cleaner Los Angeles," Los Angeles Times, I4 April 1949, I; "Women Who Seek Cleanup Gaze at Downtown Rubbish: Group's 'Shopping' Tour Directed at Elimination of Health Hazards," Los Angeles Times, I 2 April 1949, I.

${ }^{\circ}$ Jayne Morris-Crowther, "Municipal Housekeeping: The Political Activities of the Detroit Federation of Women's Clubs in the 1920s," Michigan Historical Review, 30, I (Spring 2004), 3 I-57; Seth Koven and Sonya Michel, Mothers of a New World: Maternalist Politics and the Origins of Welfare States (London: Routledge, 1993).

${ }^{9}$ As previously mentioned in my introduction, scholars can doubt or critique the intentions and results of Progressive reformers. However, it is clear that while Progressive reformers at least integrated some structural critique, mid-century cleanup leaders did not. For more information the ambivalent Progressive commitments to the poor see Alice O'Connor, 
strongly with their affiliation to the property system than as redistributive activists. If we are to look for ancestors for these women, indeed, we should look not into the Progressive Era, but rather to Lee Simpson's study of female property owners in turn-of-the-century California, where white women entered the public sphere to protect their private interests, cognizant that urban disorder threatened their property values..$^{22}$ On a methodological note, feminist scholarship has often discouraged this use of "private" and "public" to characterize women's activism. Historian Maureen Flanagan, for example, has argued that these terms have historically contributed to diminishing the ideology of female reformers, undermining them as unable to comprehend policy beyond their domestic role. ${ }^{33}$ However, categories of private and public were live elements of discourse: cleanup leaders clearly believed that the city was at its best when it resembled the private, and discarding this framework means ignoring its racial dimension. Indeed, conceptually shrinking the city as a home was a racial claim: it cast urban space as at its best when governed by benevolent white property owners, such that every problem was small enough to be fixed by "housekeeping" or cosmetic repair, thus decentring the role of a strong state and actively ignoring the fact that urban disrepair was caused by racist disinvestment from black neighbourhoods and artificial economic preservation of white ones. Domestic cities remapped public space as only successful when generating the affect of a home: quiet, neat, and free of the offensive odours, sounds, and sights associated with disorder. This understanding was not simply sociocultural, but was indeed the basis of cleanups' institutional ties with the police. If the city was a home, then it demanded protection like other forms of private property. This could involve using cleanups to encourage private citizens to discipline and denounce one another, as well as extending the mandate of the Los Angeles Police Department, announcing the neoliberal management of urban space.

Cleanups, indeed, featured a widespread endorsement of surveillance and punishment. Joe Lauer, head of the Van Nuys division of the City

Poverty Knowledge: Social Science, Social Policy, and the Poor in Twentieth-Century U.S. History (Princeton, NJ: Princeton University Press, 2000), 19.

${ }^{92}$ Lee M. A. Simpson, Selling the City: Gender, Class, and the California Growth Machine, I880-1940 (Stanford, CA: Stanford University Press, 2004), I I, 64.

${ }^{3}$ Maureen Flanagan, "The City Profitable, the City Livable: Environmental Policy, Gender, and Power in Chicago in the 191 os," Journal of Urban History, 22, 2 (Jan. 1996), 163-90, esp. I 80. Flanagan shares her concerns with other feminist thinkers and historians, such as Mary Ann Irwin, "Historians, Politics, and California Women," in Robert W. Cherny, ed., California Women and Politics: From the Gold Rush to the Great Depression (Lincoln: University of Nebraska Press, 201 I), 339-68; Anne Phillips, "Universal Pretensions in Political Thought," in Anne Phillips and Michelle Barrett, eds., Destabilizing Theory: Contemporary Feminist Debates (Cambridge: Polity, 1992), I0-3 I. 
Maintenance and Sanitation Department, asked Valleyites in 1946 to more zealously report illegal dumpers who, in Lauer's words, "persist in blighting the carefully groomed look of Valley neighbourhoods with discarded household debris." 94 In response, some civic associations formed patrols which spied on and denounced litterers. ${ }^{95}$ As a result, cleanups were often described by Valley chambers of commerce as an act of "policing," reflecting their disciplinary aspect and their hope to shame citizens. ${ }^{96}$ In one 1948 Van Nuys cleanup, for example, the chamber said it would photograph "eyesore districts" and run the photographs in the Valley Times to spur property owners to "eliminate as many blots on the escutcheon of the city as possible." 97 This insistence was energized by the folk belief that aesthetics and morality operated on a contamination model not unlike biological disease, whereby one disordered individual could spoil a whole street, thus mandating ambient intimidation. As one Los Angeles Times piece put it, "cleanliness by example tends to propagate itself, just as in reverse does filth." 98 Tellingly, cleanups received the enthusiastic support of none other than Helen Amelia Parker, wife of the chief of the Los Angeles Police Department, William Parker, who coordinated cleanups in Silver Lake and Griffith Park in $1954 .{ }^{99}$

More alarming than the propagation of social mores were the institutional transformations that groups like LAB achieved. Knudsen noted that one of LAB's prime obstacles was the "very weak" law enforcement in Los Angeles against disorder. ${ }^{100}$ This led to sustained and prolonged lobbying from LAB's leaders, who consistently pressured various legal officials to strengthen the municipality's laws to punish littering or other acts of disorder they deemed inconsistent with their vision of Los Angeles. Lola Jaques, as head of LAB's Cleanup Crusade, regularly conferred with city attorney Roger Arnebergh, who promised her that his agencies would enforce littering laws "rigorously." Arnebergh also credited the public-opinion work performed by LAB cleanups as essential to complement legal crackdowns. By the mid-

\footnotetext{
94 "War on Valley's Trash Dumpers to Clean House," Valley Times, 2 Sept. 1946, 8.

95 "Irate Pacoimans Move against Trash Dumpsters," Valley Times, 22 March 1948, 3.

96 "Rain Adds Scouring to Cleanup Campaign," Valley Times, Io April I948, 2; "Van Nuys J. C. in Cleanup Campaign," Valley Times, I I July i 957, i6.

97 “"Mayor' Devine Issues Order for Van Nuys Spring Cleanup," Valley Times, 25 March I $948,2$.

98 "For a Permanently Clean City," Los Angeles Times, 2 I Aug. 1946, I; "Spruced-Up Houses Show Improvement Drive Value: Repair Loans Up as Southland Joins U.S.," Los Angeles Times, 5 Aug. 1956, 2.

99 "Vigilantes Function in Litter Drive: Citizens Organize to Guard against Dumping of Trash," Los Angeles Times, 22 April 1954, 2; "Cleanup Drive Extended to More Communities: Four Areas Added to Three Already Slated for Final Session in Campaign Saturday," Los Angeles Times, 19 May 1954, 27.

100 "Enforcement of Laws Called Best Litter Curb," Los Angeles Times, ro Dec. 1957, C 12.
} 
I 950 , LAB broke through: the city attorney's office, as well as the city's municipal courts, promised to perform arrests for littering far more aggressively, with no warning system and maximum enforcement, thanking LAB for exerting public pressure for this change. ${ }^{10 \mathrm{I}}$ The city was remade in the image of the white middle-class home under full police protection. In 1954, as Board of Public Works inspectors carried out a wave of littering arrests, making an example by enforcing the full extent of the law, they surveyed two areas: Chavez Ravine, a Mexican neighbourhood which would later be razed to make way for Dodger Stadium, and Tujunga Wash, located in Pacoima, the only locality of the San Fernando Valley with a significant black population. ${ }^{102}$ In 1958, Los Angeles County inaugurated the first of I, 500 signs promising a fifty-dollar reward for any information leading to the arrest and conviction of a litterer. The ceremony to erect the first sign, attended by Knudsen, was located on I68th Street and Central Avenue, in Compton. If signs went up everywhere in Los Angeles's unincorporated territory, the choice to locate the first in a city with a 40 percent black population, albeit a middle-class one, adjacent to Watts and Willowbrook, is indicative of the kinds of geographies that cleanups and law enforcement reproduced. ${ }^{103}$

There is a lack of authoritative data on the racial makeup of those fined or arrested due to this crackdown. However, given the notorious racism of the Los Angeles Police Department, and its tendency to perform arrests on nebulous charges such as roaming or disturbing the peace, extending the department's mandate was itself a racialized act. ${ }^{104}$ Consistent with arguments made throughout this article, it is doubtful that LAB pursued extensive LAPD involvement specifically to punish black and Mexican Angelenos. As Loïc Wacquant argues in his work on carceralism, attributing carceral expansion to an "omniscient strategist" whose apparatus is "automatically beneficial to some abstract machinery of domination and exploitation" deforms the manifold

101 "Litter Law Ignored," Los Angeles Times, 20 Dec. 1954, I; "Litter Law," Los Angeles Times, is April I955, I; "Litter Law," Los Angeles Times, 23 June 1955, I; "Litter Law Aid Seen in Trash War: Legal Weapons for City Cleanup Found in State Measure," Los Angeles Times, I 3 April 1955, I. "Crackdown Promised on Litterbugs: Law Enforcement Agencies to Step Up Drive on Culprits," Los Angeles Times, 26 Sept. 1956, 2.

102 “i 2 Will Be Tried under Litter Law: Trial Regarded as First Real Test of City Measure,” Los Angeles Times, 22 March 1954, 2.

103 "Litterbug \$50 Reward Signs Slated," Los Angeles Times, 24 Jan. 1958, I; "Moratorium on Veterans Home Financing Signed," Los Angeles Times, 4 July 1957, 10; Josh Sides, "Straight into Compton: American Dreams, Urban Nightmares, and the Metamorphosis of a Black Suburb," American Quarterly, 56, 3 (Sept. 2004), 583-605, esp. 588-90.

${ }^{104}$ Kelly Lytle Hernandez, City of Inmates: Conquest, Rebellion, and the Rise of Human Caging in Los Angeles, I77I-I965 (Chapel Hill: University of North Carolina Press 20 I7), I 47-48; Elizabeth Escobedo, "The Pachuca Panic: Sexual and Cultural Battlegrounds in World War II Los Angeles," Western Historical Quarterly, 38, 2 (Summer 2007), I33-56. 
layers of intent and action which resulted in America's prison state. ${ }^{105}$ Instead, it was LAB's failure to perceive or care that police expansion endangered those outside the white middle class, subsumed by an ethnocentric fixation on how they thought a successful city functioned, which explains this choice. Of course, one perspective does not eliminate the other: racism structured this ignorance. Cleanups made the position of black and Mexican Angelenos more fraught in a city whose civic leadership became fixated on order and profit, precipitating legal changes to enforce its vision by any means possible. Not only did they deliver scant resources to structurally improve neighbourhoods, but they encouraged punitive state programmes, and undermined the potential for redistributive welfare initiatives.

\section{CONCLUSION}

Through this study of cleanups, I have argued that beautification activism pursued a vision of the city hospitable only to white property owners, without identifying this model as racially supremacist, encased as it was by white ignorance. Elite white groups saw the city not in terms of its residents, but rather in terms of its economic capacity, while middle-class white groups used cleanups to express their suspicion of state programmes, ranging from the more subtle forms of local pride found in the San Fernando Valley, to the activism of Pasadena, Bunker Hill, and Riverside anti-public-housing coalitions. As noted in the introduction, much of the rhetoric and tools of postwar cleanups strikingly anticipate the neoliberal age. By the mid-1960s, American cities would become a national fixation as in a constant state of crisis, rocked by race "riots" and afflicted with debt. I 970 stagflation accelerated this perceived anguish, and programmes were rapidly put in place to gut government's capacity to provide welfare, and militarize it against poor, black, and Latinx Americans, imposing a perpetual austerity regime on American cities ruled over by autocratic private-public partnerships whose only priority was profitability. Worsened by the basic bipartisan agreement of the r 990 os that neoliberalism was the antidote to America's ills, the close of the twentieth century saw cities guided by what Neil Smith refers to as "revanchist urbanism": the reconfiguration of the basic assumption that government should ensure decent living standards into punitive measures to eliminate those people perceived as blighting the city for the white middle class. ${ }^{106}$ Quality-of-life

${ }^{105}$ Loï J. D. Wacquant, Punishing the Poor: The Neoliberal Government of Social Insecurity (Durham, NC: Duke University Press, 2016), xviii.

${ }^{106}$ Kevin Fox Gotham, Crisis Cities: Disaster and Redevelopment in New York and New Orleans (Oxford: Oxford University Press, 2014), 27-30, 46-48; Oliver D. Cooke, Rethinking Municipal Privatization (London: Routledge, 2007), I-16; Jason R. Hackworth, The 
laws, referring to ordinances which criminalized immaterial erosions of public order such as loitering, were brought back by the neoliberal age, having been struck down from American courts in the 1960 s thanks to the civil rights movement, as broken-window policing urged communities to police any and every sign of disorder in their neighbourhood to guard it from social and physical insecurity. ${ }^{107}$ Cleanups would feature in this revival: a comparative study of I 990 s community policing in Portland, Oregon, Savannah, Georgia, Minneapolis, Minnesota, St. Louis, Missouri, and Los Angeles found that cleanups had become a "common element" of policing programmes, with citizens organizing work parties and officers providing security. ${ }^{108}$ Cleanup coalitions were set on privatizing public space, reducing the state's ability to provide welfare, encouraging its punitive capacity, and enshrining a legal and policing regime which tried to criminalize minor offenses, leading to the enforcement of preexisting racial geographies of crime and disorder. In this sense, cleanups powerfully exemplify the continuity between the postwar period and the neoliberal age. They reveal the social aspect of this prehistory of neoliberalism, wherein white Americans' visions of a more successful urban environment were dominated by individual responsibility, privatization, and state austerity wedded to carceralism.

Cleanups, I have argued, are best comprehended through the lens of white ignorance. Amid the postwar reformulation of racism, cleanup leaders were guided by an optimistic reading of urbanism, wherein filth or disorder could be vanquished if citizens displayed gumption and recast the city in the image of the private home. The outcome, however, materially involved expansion of police power, and had stark racial outcomes, as did urban renewal programmes endorsed by LAB, and the activism against public housing featured across southern California on the coattails of cleanups. Foregrounding white ignorance does not mean that these groups were free of racist participants, or indeed of racist intent. However, white Americans could easily align with

Neoliberal City: Governance, Ideology, and Development in American Urbanism (Ithaca, NY:

Cornell University Press, 2007); Neil Smith, "Which New Urbanism? The Revanchist '90s," Perspecta, 30 (1999), 98-105.

107 Dorothy E. Roberts, "Foreword: Race, Vagueness, and the Social Meaning of OrderMaintenance Policing," Journal of Criminal Law and Criminology, 89, 3 (Spring 1999), 775-836, esp. 783, 80 I-4; Gary Stewart, "Black Codes and Broken Windows: The Legacy of Racial Hegemony in Anti-gang Civil Injunctions," Yale Law Journal, 107, 7 (May 1 998), 2249-79, esp. 2250-54; 2262-63; Debra Livingston, "Police Discretion and the Quality of Life in Public Places: Courts, Communities, and the New Policing," Columbia Law Review, 97, 3 (April 1997), 55 I-672, esp. 556, 56 I, 586, 594.

${ }^{108}$ Dan Fleissner, Nicholas Fedan, and Ezra Stotland, South Seattle Crime Reduction Project: A Descriptive Study of Community/Police Cooperation in the City of Seattle, (Washington, DC: National Institute of Justice, I991), I 25. 
a project which staked urban order as a matter of individual will, broke state ability to intervene on a structural level, entrusted the police with community management, and could do so without identifying this affiliation as racist, since these components broadly functioned for the white affluent American experience. Certainly, America's racialized social system is guarded by committed racists with a competent grasp of postracial language which can pass as white ignorance. I propose, however, that the study of ignorance allows scholars to untangle how white Americans amass resources while failing to identify as harmful. The racism of white ignorance, as this article makes clear, far exceeds a simple lack of access to fact. Instead, it is embedded in the distribution of property, allocation of services and infrastructure, sociability, relation to the state, and economic interests.

\section{AUTHOR BIOGRAPHY}

Vincent Chabany-Douarre is a Doctoral Candidate at King's College London, supported by the London Arts and Humanities Partnership. He extends thanks to Uta Balbier and Daniel Matlin for their feedback on this article. This research was generously supported by grants from the London Arts and Humanities Partnership, King's College Arts and Humanities Faculty, King's College History Department, UK Research and Innovation, and the Huntington Library. 